\title{
Manufacturing paradigms and their change in time
}

\author{
Štefan Mozol ${ }^{1}$, Patrik Grznár ${ }^{1}$, Matúš Oravec ${ }^{2}$ \\ ${ }_{1}$ University of Žilina, Faculty of Mechanical Engineering, Department of Industrial \\ Engineering \\ Univerzitná 8215/1, 01026 Žilina, Slovakia \\ stefan.mozol@stroj.uniza.sk \\ patrik.grznar@stroj.uniza.sk \\ ${ }_{3}$ Slovak University of Technology, Faculty of Electrical Engineering and \\ Information Technology - Institute of Robotics and Cybernetics \\ Ilkovičova 3, 81219 Bratislava, Slovakia \\ matus.oravec@stuba.sk
}

\begin{abstract}
Annotation: Manufacturing companies are constantly confronted by changes in customer behaviour, which affects their product strategy. The product strategy of the enterprise or the manufacturing paradigm represents how the company approach to producing products in terms of its quantity and variants. Various changes over time also led to a change in the production paradigm of enterprises, it also influenced the development of manufacturing approaches by which the paradigm is implemented. The article describes the different manufacturing paradigms their change over time, and which manufacturing approaches will be deployed within the paradigms.
\end{abstract}

\section{Introduction}

The relationship of the enterprise to the customer changes over time. If in the past some products have been produced mass in as much quantity as possible to meet demand, then over time the markets have become crowded, and if company want to sell its product, it must respond to a change in customer requirements. Future manufacturing systems will be significantly different from those of today. The changes will be due not only to customer pressure on the variant of new products but also by revolutionary changes due to technological innovation. The most significant factor that affects the existing production environment is the customer. He wants to configure his future product in detail today and does so online. Manufacturers are therefore more compelled to develop online digital configurators of their products. The digital model of the future product serves as an order. The manufacturer implements it in a method of Make To Order (MTO). Some customers want to be present at the "birth" of their product, they want to see with their own eyes how it is produced. Therefore, several manufacturers are already allowing their customers such an experience through the concept of the so-called Glass Factory [1]. Today's market world is characterised by the individualisation of customer requirements. If a manufacturer wants to sell its products, it must bring new value to the market, new products with different characteristics that customers will appreciate and buy. The manufacturing 
paradigm represents how the company is approaching the manufacturing of products in terms of its quantities and variants. Today's customer requirements are linked to the growth of product variant, which has a negative effect on production lead time and costs. For current manufacturing companies, the strategy of mass customisation is becoming increasingly attractive, but effective implementation is not possible without advanced manufacturing systems capable of responding quickly to changes [2]. The highest form of customer satisfaction is the personalisation of demand. This means that each product is tailored to the customer. From the principle of press and pull changes in the company, we know that the customer is making a move on new products and the organisation is forced to change its current view of production. The growth of requirements for new customised products puts high pressure on brand new manufacturing system concepts. Today, with the coming of a new stage of product personalisation, the company must be able to quickly individually produce a wide range of products. This has a huge impact on production and on its changes. These courses need to be responded by developing new manufacturing concepts capable of meeting these requirements. The article deals with the description of the different manufacturing paradigms of their change over time as well as the systems that will be deployed within the paradigms.

\section{Development of manufacturing paradigm in time}

The development of paradigms over time is associated with changing customer requirements and their needs. In general, according to [3], four basic approaches to production can be identified:

- Craft production - the manufactured product is intended for a particular customer and can therefore be described as a 'one customer's market'. This is a pull business model.

- Mass production - produced is a narrow range of products, a constant demand is assumed. This is a press business model.

- Mass customisation - customer chooses from a wide range of options before the production itself. The manufacturer makes the main decisions on the basic structure of the product as well as on the number of variants and options offered based on the target group of customers (market segment). The customer chooses from the portfolio on the basis of his own criteria. It is currently one of the most common uses of the production approach. This is a pull-push business model.

- Personalised production -this is production according to the customer's configuration. This approach aims to offer the customer a share of the design of the product itself. However, there is an increased requirement for manufacturing systems in the configuration area for the production of a wide range of products. This is a pull business model. 
Each manufacturing paradigm has had a different set of imperatives that came either from societal needs or from market forces, as seen in Table 1.

Table 1-Manufacturing Paradigms and Their Drivers [4]

\begin{tabular}{|c|c|c|c|c|}
\hline Paradigm & $\begin{array}{c}\text { Craft } \\
\text { Production }\end{array}$ & $\begin{array}{c}\text { Mass } \\
\text { Production }\end{array}$ & $\begin{array}{c}\text { Mass } \\
\text { Customisation }\end{array}$ & $\begin{array}{c}\text { Personalised } \\
\text { Production }\end{array}$ \\
\hline $\begin{array}{c}\text { The } \\
\text { individual }\end{array}$ & The product & $\begin{array}{c}\text { Market } \\
\text { segments }\end{array}$ & $\begin{array}{c}\text { The } \\
\text { individual }\end{array}$ \\
\hline needs & $\begin{array}{c}\text { Tailored- } \\
\text { made } \\
\text { products }\end{array}$ & $\begin{array}{c}\text { Low-cost } \\
\text { products }\end{array}$ & $\begin{array}{c}\text { Large product } \\
\text { variety }\end{array}$ & $\begin{array}{c}\text { Personal-fit } \\
\text { products }\end{array}$ \\
$\begin{array}{c}\text { Business model } \\
\text { principle }\end{array}$ & $\begin{array}{c}\text { Pull } \\
\text { Sell- } \\
\text { Design- } \\
\text { Make }\end{array}$ & $\begin{array}{c}\text { Push } \\
\text { Design- } \\
\text { Make-Sell }\end{array}$ & $\begin{array}{c}\text { Push-Pull } \\
\text { Design- } \\
\text { Sell-Make }\end{array}$ & $\begin{array}{c}\text { Pull } \\
\text { Design- } \\
\text { Sell-Design } \\
\text {-Make }\end{array}$ \\
\hline
\end{tabular}

The long-term success of each business depends on meeting emerging social and market needs. In view of this, each company must aspire to respond to these trends by its manufacturing systems. In the case of craft production, universal machine tools were needed, capable of producing a wider range of products. However, upon the arrival of mass production, these facilities were replaced by single-purpose production lines which were able to meet constant mass demand at low production costs and prices. However, markets have been over time, and demand has not been constant but was foreseeable. The customer started searching for products that matched his requirements at a low price. At that point, the market ceases to be homogeneous and is starting to show a wide range of products. Flexible production systems have begun to be applied in order to be able to meet these needs. They were able to produce diverse production in need of market stability. However, as globalisation progresses, this market stability is losing out, fluctuations in demand are created, and this opens the way for a reconfigurable manufacturing system. These allow us to set the necessary production capacity according to market demand and rapid adaptation of their functions to produce multiple product variants. It is reconfigurable manufacturing systems that allow the development of future manufacturing systems for personalised production. The development of manufacturing systems and approaches, depending on time, is illustrated in Figure 1. 


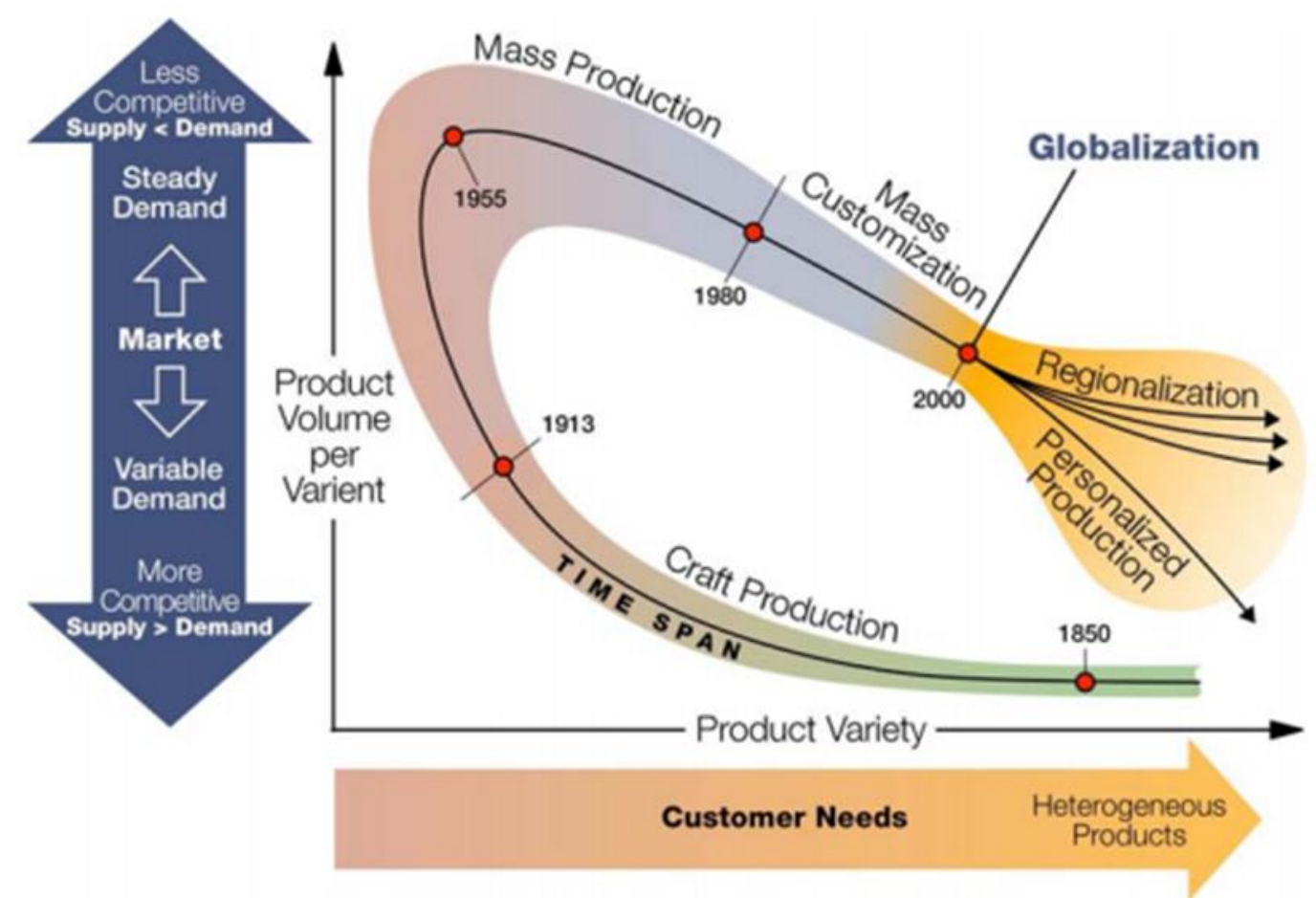

Figure 1 - Development of manufacturing paradigm base on time and manufacturing approaches [4]

\section{New manufacturing approaches}

The production environment is characterised by constant change due to turbulent market environments and paradigm shifts. Modern society and technologies produce an impatient customer. It constantly looked for new products with better properties, better functionality and possible product customisation. On the result, many of the manufacturers needed to react on constantly changing condition [5]. In the past, businesses have made changes in an extensive way, which is a way out of a one-off reaction to change [6]. The new progressive approach is based on the application of the system, which is capable of a different reaction to change and at the same time a change within time based competition (TBC). Under the time competition, we understand the change, which on one side press on product customisation, thanks to what markets stay heterogenic and shorting life cycle of products. This is due to the reduction of time for the development of products also as placing it on the market (Time to Market). On the other hand, it is changed in new technologies and materials, which are designed to press on innovation, what is reflecting is constantly effort to configure the product base [7]. In the global market, the time and time placed on the market is an important competitive advantage. For the obtained this advantage, new manufacturing approaches are developed. Some of them are:

- Quick Response Manufacturing (QRM). 
- Reconfigurable Manufacturing Systems (RMS).

- Competency Islands $(\mathrm{Cl})$.

- Reconfigurable Logistics System for Factory of the Future (RLS_FoF).

Each of the named manufacturing approaches has its characteristics, application areas and the specific problem that they solve. The production approach of manufacturing with the quick response is characterised by the fact that the application can achieve optimisation of the activities of the enterprise, both internal and external at the process level. So it's usable where it's difficult to apply Lean Management. It is suitable for low volume and highly variant production, where each product has a specific form, different from the others. Production using reconfigurable production systems is characterised by the possibility of rapid change of its hardware (equipment) and software (programs) components so that a rapid change of the manufactured product can be achieved, at the lowest possible time needed for conversion, thereby increasing the capacity load of equipment on the line. The application of such systems is expected to be taken by manufacturers who are forced to react quickly to changes in market requirements, which from applicability point of view is appropriate for the manufacturers (subcontractors) in for final assembly. They are suitable for production with high variability from the product family point of view. The difference between Quick Response Manufacturing and RMS is that the first is more focused on processes, while RMS is focused on changing production capacity as such from the point of view of hardware and software. The competency islands are a production approach where production is divided into a manufacturing island where there is no fixed link between the islands, and the transport of the processed product is provided by mobile automatic platforms (MAP) means and for the configuration of islands and elements is using mobile robotic systems (MRS). The primary purpose of the application is the same as for RMS, in the difference that the competency islands are intended primarily for the final assembly of the product. The approach is designed to produce a wide range of selected product family. The reconfigurable logistics system for the factories of the future is characterised by the high autonomy of the elements in the decision making and will find their application is as a support system to other approaches such as RMS and competency islands. They enable the real-time creation of a dynamic route of transport and handling equipment, which is a key prerequisite for the application of new manufacturing approaches.

\section{Conclusion}

Change in the today's world is more frequent and visible, especially in the area of customers requirements. The intend of manufacturing companies is to reach the customer with their product strategy (paradigm). In the time, companies try to respond to customer demand through different manufacturing paradigms, from a piece production on the beginning of the 
industrial revolution to current trends of mass customisation and personalisation. In the past, the company had to respond to the trends also with its manufacturing approach. According to the paradigm of mass manufacturing, many manufacturing lines were composed as a flexible manufacturing line. For today's trend is characteristic decentralisation of production and more spread use of object autonomy, which is due to the technological progress intelligent. This new generation of manufacturing systems is designed for the factory of the future which changes the world of manufacturing as we know it.

\section{Acknowledgments}

This work was supported by the Slovak Research and Development Agency under the Contract no. APVV-14-0752.

\section{Literature}

[1] GREGOR, M., et al. Budúce továrne - Technologické zmeny a ich vplyv na budúce výrobné systémy. Žilina: CEIT, a.s., 2017, 46 s. ISBN 978-8089865-01-7.

[2] HALUŠKA, M. Rekonfigurovatelné výrobné systémy. Žilina, 2015. Diseratation thesis. University of Žilina. Faculty of Mechanical Engineering

[3] VAVRÍK, V. Projektovanie produkčných liniek s využitím princípov rekonfigurácie. Žilina, 2019. Diseratation thesis. University of Žilina. Faculty of Mechanical Engineering.

[4] KOREN, Y. The Global Manufacturing Revolution Product-Process-Business Integration and Reconfigurable Systems. New Yersey: John Wiley, 2010, 416 s. ISBN: 978-0-470-58377-7.

[5] SURI, R. QUICK RESPONSE MANUFACTURING: A companywide Approach to Reducting Lead times. Portland: Productivity Press, 1998, 576 s. ISBN 1-56327-201-6.

[6] GREGOR, M., MIČIETA, B., BUBENÍK, P. Plánovanie výroby. Žilina: EDIS, 2005, 173 s. ISBN 80-8070-427-9.

[7] GREGOR, M., HALUŠKA, M., GRZNÁR, P. Komplexné systémy. Žilina: CEIT, 2018, 107 s. ISBN 978-80-89865-10-9. 